\title{
Research on the Measures of Strengthening the Effectiveness of Ideological and Political Education in Colleges
}

\author{
Zi-ye Li \\ Social Science Department \\ Hebei Finance University \\ Baoding,China
}

\begin{abstract}
The teaching of ideological and political theory in colleges is the main way to carry out the ideological education for college students, and it plays an important role. Under the joint efforts of major universities, ideological and political education has made remarkable achievements. But with the change of situation and social environment, college students presents new characteristics, thinking and political course contents of the old can not be followed by the change, teaching methods also followed them mechanically, and students learning enthusiasm is not high. The innovation and enthusiasm of ideological and political teachers is not high. In addition, there is lack of management of teachers. The feedback mechanism of the teaching is imperfect, the information feedback channel is blocked, and the teaching is ineffective. The existence of the above problems, reduces the education effect of ideological and political theory course.
\end{abstract}

Keywords: Ideological and political education; Effectiveness; Feedback

\section{INTRODUCTION}

Colleges and universities undertake the social responsibility of training personnel output. Shaping the young college students who have culture, ideals and morality is the goal of college education. In the process of implementation of educational knowledge, ideological and political education can not be slack. Through the creation of ideological and political courses, college students accept the baptism of advanced ideas, with Marx and Mao Zedong thought armed with the mind, and actively guide practice. They also should establish the correct life outlook and values, in the face of the complex and volatile external environment, always keep a clear mind, consciously to prevent the intrusion of decadent ideas, keep from the negative effects of the stale ideas, inherit the tradition of patriotism, and promote the national spirit, at any time can always firm ideal and faith, adhere to the socialist road and support of the party and the state leadership, dare to undertake the heavy responsibility of the socialism construction, march forward courageously. ideological and political course importance is known to everyone, and how to further enhance the effectiveness of ideological and political course is urgent to solve ${ }^{[1]}$.

\section{The ideological and political lesson set and content need to be improved with the times.}

Most of the young college students do not live up to the Party and the country's expectation, inspirational self-cultivation, embarked on the road to success. But with the spread of unhealthy social atmosphere, utilitarianism and money worship and other decadent ideas brought negative effects on college students growth, and college student' ideological and political education should be further improved. But in many colleges and universities, ideological and political lessons are less than the professional course, some content only gives the superficial explanation. Thus, the content of students learning in the classroom is also limited, and the depth is not enough. Ideological and political courses lay particular stress on theoretical knowledge, so the current college students 
gratitude consciousness is weak, have no responsibility, lack of honesty and credit, individualism, the university student illegal crime and specific education content is less. In ideological and political course, students are only repeated instillation theory, which is divorced from reality and the guidance is not strong.

The ideological and political education is as important as the education of the specialized course, and the college should pay the same attention to the education. With the increasing of enrollment, colleges should strengthen the infrastructure, expand the classroom, improve the teaching environment, meet the teaching needs, improve the teaching efficiency, set the ideological and political course and the professional course go hand in hand, provide more time for students to learn ideological and political course. Moreover, teachers can also spend more time on explaining and improving the quality of student learning. In order to make the ideological and political theory course better play its role, the content set should be avoided the duplication, and add new content. Ideological and political theory course content should be emphatically to the actual, advancing with the times, recognize the negative impact of the social situation of college students, increase college students' patriotism, gratitude, integrity, and civilization, and effectively solves the problem of college Students ideological and moral status in the rapid development of economy $^{[2]}$.

\section{The teaching method of ideological and political education needs to be improved.}

In order to strengthen the effectiveness of ideological and political education, improving teaching method is the key, which directly affect the quality of teaching. The ideological and political theory is very abstract. Teachers and students generally think that ideological and political course is nothing more than rote learning. A lot of ideological and political teachers only know blindly indoctrination, and neglect to guide students to comprehend its connotation and realm. Thus, students can only know the surface in stead of its essence, which is not up to the ultimate goal of the enlightenment education.
College should take the important thinking seriously, put the teaching reform of ideological and political course into the agenda, and study the effective way to improve the quality of ideological and political education. Strengthen the supervision of the teaching process, and urge teachers to improve teaching methods, and actively innovate, so that ideological and political lesson can be positive. According to the basic content of ideological and political textbooks, combining with the actual situation of college students, colleges should regard the ideological and moral education as the breakthrough point, and carry out special education in patriotism, ideal and belief, moral civilization, integrity gratitude, legal security. Students can give full play to their subjective initiative in the classroom, so that each student can actively express their ideas and insights. Teachers ought to guide students to actively think about the problem, explore and find a unified answer, which can not only mobilize the students to learn more positively, but also deepen the students' understanding of knowledge. In addition, colleges should actively explore the "second classroom", take full advantage of the excellent teacher resources, guide the various classes to carry out the debate contest, speech contest and other forms of activities.

\section{The team construction of ideological and political education should be strengthen.}

For the cost of running school, many private colleges and universities reduce the number of ideological and political teachers, resulting in ideological and political teachers in short supply and the proportion of serious imbalance between teachers and students. The teachers tend to be younger who are still in the exploration stage. Thus, the teaching experience is insufficient, the teaching method is poor, and the knowledge experience is deficient. Colleges lack adequate supervision to teachers. Many teachers are satisfied with the current status, lack of spirit of enterprising and innovation. Teachers' scientific research ability is not strong, lack of effective guidance, and research enthusiasm is not high.

Strengthening the construction of teachers' team is imperative. In order to carry out teaching activities more 
effectively, it is necessary to increase the number of teachers, which can meet the balance between supply and demand. In the process of introducing teachers, the standards and requirements should be in a high level. In addition to professional qualifications and strict requirements, the work time, professional title of ideological and political education should also be the hiring standards and strictly implemented, so as to prevent cohabitation from the source. Colleges are expected to strengthen the management of teachers, rectify the bad habits in the teams, improve the moral quality of teachers and create the positive enterprising team. The special training of ideological and political team is planned, and the comprehensive quality of the teachers' professional ability, teaching ability and scientific research ability are gradually improved. There are some other measures to improve the construction of teacher team, such as strengthen intercollegiate exchange learning experience, create more research opportunities, take incentives to encourage political and ideological teachers to carry out research activities, mobilize the initiative and enthusiasm of teachers $\operatorname{research}^{[3]}$.

\section{The feedback mechanism of the ideological and political education need to be improved.}

Whether students can gain knowledge in teaching activity, and they can really benefit is an important yardstick to test the quality of teaching. But many colleges and students information communication is not smooth, and do not build a feasible channel of information. Therefore, students' opinions on teaching have no place to say, and college can not timely listened to the teaching reflection from students. Higher education assessment system is not perfect, the major colleges and universities are in the implementation of teaching evaluation system, but the implementation is not in place, contents of teaching evaluation is simple, not comprehensive and detailed, which can not reflect the achievements and problems. It is difficult to achieve the purpose of evaluation of teaching.

Colleges should establish a sound teaching feedback mechanism, actively broaden the information channels, and ensure that the information between students is unimpeded. The student reception should be set up, specifically for students to reflect on the issue of teaching, humbly listen to student feedback, and great importance to students by providing valuable advice A network platform for each course of each teacher is worthy to build. In the platform, students can make evaluation of the relevant teachers and courses, timely reflect the problems. Teachers should hold a student forum regularly, collect the views and suggestions of various classes, understand the teaching situation, and follow up the questions to the students' questions. Colleges should earnestly implement the evaluation and education system, and further improve the contents of the assessment, in order to keep it comprehensive and detailed. Because the traditional model can not reflect the degree of knowledge understanding, To explore the new mode of ideological and political education actively is necessary. The Exam content should contact the recent hot events, try to use various forms, such as speech, social practice investigation report and so on, in order to enhance ideological and political teaching results.

\section{Conclusions}

The ideological and political course is an important way to carry out ideological and political education, and colleges should actively explore new methods, new ideas and give full play to the educational role of ideological and political education. College students should attach importance to ideological and political course learning, and gradually establish a correct life outlook and values, use advanced thoughts to guide their practice,and show the good image of young college students. 


\section{References}

[1] Wu Wei, "Constraints and Countermeasures for Effectiveness of Ideological and Political Education in Vocational Institutions," Journal of Taiyuan University, pp. 65-67, 2011.

[2] Yang Bangyong, "Enhancing the efficacy of ideological education of college students in social transition,"
Journal of Fujian University of Technology, pp. 626-629, 2008.

[3] Zhang Yingshuai, "Enhance the Actual Effect of Ideological and Political Education," Journal of Anshun University, pp. 38-39, 2014. 